\title{
INFORMATION SHARING IN TELEGRAM GROUP OF INDONESIAN BOOK FORUM
}

\author{
Nuning Kurniasih \\ Universitas Padjadjaran \\ email: nuning.kurniasih@ unpad.ac.id
}

\begin{abstract}
Indonesian Book Forum or Forum Buku Indonesian is a forum for Indonesian books lover in Telegram. This group enables the members to discuss over, share, and exchange books or information about books, including e-book. This study aims to investigate books information exchange in Telegram Group of FBI by observing the interaction in the group, the collecting process, analyzing, validating and investigating, information sharing and education in Telegram Group of Forum Buku Indonesia. This is a qualitative study using virtual ethnography method. The data collection of this study incorporates participative observation in the group since February to July 2017, in-depth interview and literature study. The informant was chosen based on purposive sampling technique. Triangulation is done by theories triangulation. The results show that there is no guarantee the Telegram group of Forum Buku Indonesia can provide every book or information request. Everything is done voluntarily. The group admins play the role to encourage the members to participate actively in sharing books information and help other members to find the books needed. There is also information exchange on how to use Telegram besides information exchange of books. These rules of group placed on Pinned Message feature. The most founded information shared is books file forwarded from other group or Telegram channel. In order to identify the members' information needs, they are asked to write down their information needs specifically. Books sharing done by forwarding information from other group or channel, while resume and meta data of books, sharing links of books or e-books file can be downloaded directly. Admins and the members share information from other group or channel always include the information sources. The education process is given by asking the members to read the rules regarding books finding include using search menu on Telegram in order to check whether the books needed have been posted before or not. This research is expected to contribute to the government in increasing the reading interest of the community in the digital era.
\end{abstract}

Keywords: information sharing, reading habit, reading resources, computer mediated communication

\section{INTRODUCTION}

Indonesian Book Forum or Forum Buku Indonesian (later will be addressed as FBI) is a forum for Indonesian books lover in Telegram. This group enables the members to discuss over, share, and exchange books or information about books, including e-book. It was established on February 26th, 2017 as a super group by Sartana. There are 2400 members and more than 5000 links and e-books shared in this group until July 30th, 2017. Telegram was chosen as the media to share information because it provides simple features, speed connectivity, all devices synchronized enables message to be accessed by any devices, enable sharing and sending unlimited size of files and media because it is automatically saved in the Telegram cloud, security guarantee, Secret Chats feature enables to protect users' privacy, its group chats can accommodate up to 10.000 members, reliable because it enables to send message with minimum bites, it is fun because it has photo and video editing feature also enables GIF format stickers, free apps and also ads free (Telegram Messenger LLP, 2017). Internet activities include accessing, browsing, saving, 
publishing, and information sharing are increasing because of the computer technology collaboration uses (Jackson, 2000). Information sharing is information exchange activity among people who can access information gathered or maintained by the other (Calo, Cenci, Fillottrani, \& Estevez, 2012). Information sharing is also a part of knowledge management. McElroy describes knowledge life cycle in five processes that is production, organizing, integration, distribution, and business process environment where information sharing is the part of knowledge integration sub process (Dalkir, 2005). This study aims to investigate books information exchange in Telegram Group of FBI by observing the interaction in the group, the collecting process, analyzing, validating and investigating, information sharing and education in Telegram Group of FBI. This research is expected to contribute to the government in increasing the reading interest of the community in the digital era.

\section{RESEARCH METHOD}

This is a qualitative study using virtual ethnography method. Virtual ethnography method requires researcher has to actually understand the virtual environment of the research object includes the space, time, validity, identity and ethics applied in that virtual environment (Steinmetz, 2012). Thus, the data collection of this study incorporates participative observation in the group since February to July 2017, interview and literature study. The informant was chosen based on purposive sampling technique. Thus an admin and also the most active member during the period of June to July 2017 was chosen as the informant. Triangulation was done using theories triangulation. Data analysis done by combining and interpreting data obtained from the field (Genzuk, 2003).

\section{FINDINGS AND DISCUSSION}

\subsection{Interaction in Telegram Group of FBI}

In the beginning of its establishment, there were no clear rules on what and how to share books information in the Telegram group of FBI. The initial communication happened in the first place included greetings, thank you note for the FBI join invitation, compliment for the group, technical questions on how to use Telegram, such as how to move files from internal storage to external memory card; on why group media cannot be downloaded; on how to install Telegram on PC desktop, etc. Also, in the beginning of its establishment, the one who shared the most books and book links is the creator who is also the group admin. Group members asked for books by sending direct question, such as "Do you have book titled Education Psychology?" or "I need book regarding decision support system in computer, any leads?" or "Anybody knows book about Cosmic Intelligence?", then other members would reply, such as "You can search for it on gen.lib.rus." Then, there was a member asked to organize the books already shared thus it would not scatter around. The admin then asked that member to help organize it. Another member then suggested that there is a feature provided by Telegram for that purpose that is by clicking the forum name above then choose "share media" (FBI, 4/3). This type of interaction indicates there is also information exchange on how to use Telegram besides information exchange of books. In the respond to the inquiry regarding organizing the books shared in the group, other member suggested to use the hastag \#sedekahbuku (book alms), where he explained that the hastag \#sedekahbuku is a movement run by other community. Thus, the group admin then warned the members that they are only allowed to post things related to books (FBI, 4/3). Other member then also suggested there should be posting rules, such as it is not allowed to post issues regarding religion, politic, ethnic, race, and anything other than books (FBI, 11/13). Therefore, group members need guidance on how to interact in the group and this guidance eventually will become a culture. Information culture is generated by the values and behaviors of individuals and 
organization, which represents their values and attitude toward information, the does and does not in the process, publication, and communication of information (Davenport, 1997). As the respond to this matter, some members then offered themselves as the group admin, which responded by the original admin/creator by opening the offer to the whole members and currently FBI Telegram group running with five admins in total (FBI, 20/3, 1,3/4). On June 1st, 2017, one of the admins launched the group rules including what is allowed and not allowed to share in the group, how to use feature "search media" to find the books already shared before to avoid repeated request, the necessity of using polite language and clear information when asking for books, the format for book request using hastag \#request_book title_author to enable other members browse for the books, a statement from the admins that there is no guarantee the group can provide all inquiries and a request for all the members to participate actively in helping others' books needs (FBI, 1/6). These rules then placed on Pinned Message feature, which is a Telegram feature enables message to be placed on the top of message board thus it will be visible to all members. Besides the rules on the pinned message feature, the group admin also posted a warning in the group that members with vogue identity and/or post things unrelated to the group will be removed from the group and that all members requested to actively participate in observing it. The success of knowledge sharing is awareness, access, applying same language, and mutual understanding in sharing also having mutual perception in order to maintain respect and values (Tsui, Chapman, Schnirer, \& Stewart, 2006). One-way communication is unavoidable, when there is no respond to certain inquiry or book request since there is no guarantee the Telegram group of FBI can provide every book or information request. Everything is done voluntarily. The group admins play the role to encourage the members to participate actively in sharing books information and help other members to find the books needed.

\subsection{Information Collection Process}

The creator/admin group posted in the group that the members only allowed to post information related to books, including new books, literation movement, free books/e-books, link web, inquiries regarding books or other related things and that the admins will delete any unrelated post (FBI, 5/3). Based on the observation, the information shared in the group including pdf files, e-pub, resume, books content, books cover, information regarding the newest books published, suggestion for books draft will be published such as the book draft titled "Buku Saku: Panduan Latihan Fisik Eksentrik Berbasis Self pada Diabetes Melitus by Andri Setiya Wahyudi" (FBI, 4/3), where to find certain books, information regarding books publisher, books selling, books location, books request, the list of serial books such as Sidney Sheldon novels (FBI, 12/3), e-book files along with its meta data such as summary, maturity, categories, language information, words count, sentences count, reading duration, file format and rating such as on the e-book of The Complete Sherlock Holmes by Sir Arthur Conan Doyle (FBI, 13/3), account and Telegram channel of free e-book (FBI, 17/3), audio books (Podcast), books link forwarded from the group, inquiry regarding list of indexed journals, free e-book link such as book.fi, maketecheasier.com, etc. The most founded information shared is books file forwarded from other group or Telegram channel. There are a lot of groups or Telegram channel become the information sources of FBI group that is MF Mix EBooks, Bookwarms, Teaching English M.A., Thesaurus Words IELTS \& Books, Cardiology, International Mediacal Centre, Anesthesia Books, SDGT Book Store, Medical Physics Library, The Pengun Lesson, Luther's Fortress, Academic Books, Eboolz Collection, The X-Files Books and Magazine, Anon Free Library v2.0, Linguistics Library, ELT Books \& Journal Article, etc. In order to get free e-book one day limited the members shared packtpub.com in the group. Besides other group or Telegram channel, the group members also gather information from the colleges with e-book subscribe and also by asking their friends from 
other communities. The subjects shared in the group are varied including medical, English, technology, research methods, social sciences, etc.

Meanwhile, members who need books or information about books usually send their inquiries in the group. Although there is rule that members have to check the "search media" feature using hastag \#request before posting book request in the group, some members still ignore it. The admins and other members often remind to use the feature "search" using the hastag since the books requested have been shared before. For instance, a member asked "Is there any book about logical thinking for child?", "Any book about art?", "Anyone has e-book for english practice?" and other members responded with "there are a lots of it. You can find it on Shared Media". Since it is one of the most repeated issues in the group, one of the admins then created a vote by asking "Do you understand how to find a book in this group using feature 'search'?". The result shows that out of 49 respondents participated in the voting, 27 respondents (55\%) replied, "already know and always waiting for it", 13 respondents $(27 \%)$ replied, "already know but seldom using it", and 9 respondents (18\%) replied, "do not know". Hatala and Lutta conclude some of the obstacles in information sharing includes (1) in the context of organization, some organizations limit its information sharing because of industry espionage awareness; (2) individuals will keep the information only for himself if it is endangering his power or position; (3) security factor, politic regulation, management decision, organization structure, and individuals position in the organization; (4) media can be a hinder in information sharing; (5) educational level differences in organization; (6) sharing can degrade the information value (Hatala \& Lutta, 2009). Thus, educational level and skill differences of the group members in using Telegram features will be one of the obstacles in information sharing. Besides, almost all of the link and e-books shared in the FBI Telegram group are in English, thus some members still ask for the Indonesian version of it (FBI, 16/3).

\subsection{Information Analysis, Validation and Investigation shared in Telegram Group of FBI}

Although information and knowledge have different meaning, in the context of this study the definition of information sharing as a part of knowledge sharing is still relatable. The capability frame of information sharing is the same as the knowledge sharing, which includes knowledge identification and capture, knowledge and learning product, knowledge sharing, monitoring and evaluating, partnership, financing, effective governance mechanism, and leadership and organization culture (Janus, 2016). In order to identify the members' information needs, they are asked to write down their information needs specifically. For instance, a member who needs Mathematic books needs to write down the title and author of the books in which mathematic field specifically. When there is no special needs, the admin then will help to look for the most used mathematic books. However, not all of the searching result shared in the group. An admin explains there is a selection process for the books she shared. She also admits that if she is interested with the book then she will read the book thoroughly before sharing it, but if it is not related with her interest then the selection process only based on the titles.

\subsection{Information Sharing in Telegram Group of FBI}

The Telegram group can be accessed through this link https://t.me/joinchat/AAAAAEBvIvm2nXctkHa-mQ. Members share the group link through other groups. Books sharing done by forwarding information from other group or channel, while resume and meta data of books, sharing links of books or e-books file can be downloaded directly. Admins and the members share information from other group or channel always include the information sources. Members who interested with the information sources can directly click the group or channel link shared. However, there are few members who do not know how to see the 
information sources of the forwarded message, they would ask in the group and other members would reply by asking them to click on the group or channel link shared. Drake et al. and Sinkula account that information sharing is the result of collection, dissemination, and information interpretation process (Hatala \& Lutta, 2009). There are three types of knowledge sharing (including information sharing) that is knowledge acquisition, knowledge re-use, and knowledge creation or knowledge development (Huysman \& Wit, 2002). According to the informant, information sharing in the Telegram group of FBI is not optimal yet since the contents mostly forwarded messages from other groups or channel. It is because forwarding information only requires little time and internet quota, while self-browsing will consume more time and internet quota because we have to browse, download, then upload in on Telegram. Informant herself is actively sharing information, including forwarding message, share link and e-book files with or without request. She also tries to complete the books source in the group by checking the request and e-book shared. There are many e-book subjects shared but the demand is low and otherwise, there are also many demands of certain e-book subjects but the share is low. The informant admits that he attempt to fill in the gap and that he feels content when helping people find the books needed, although he has to invest lot of time and internet quota in doing so. There is no guarantee the group can provide everything the members look for. Sometimes, when the members do not get respond from the group, they will try to reach other active admin/members through personal channel. When the request delivered considered polite by the member, then she will ask the person to post the request in the group and the book will be posted also in the group so that other members can also enjoy it. But, when the request delivered considered impolite then the member will simply ignore it. The informant usually gets positive reaction after sharing e-book or e-book link in the group, such as thank you note and permission request by other members to repost the information in other group or channel. As the mission of the group is to share information then every-shared information in the group is allowed to be re-shared to the others. The Telegram group of FBI is open for public access although not a member of the group. Viewers of one ebook in the FBI group are quite a lot, for instance the e-book titled "Perfect Phrases for the TOEFL: Speaking and Writing Sections" - Robert G. Steinberg has been viewed by 11.400 viewers by July 30th, 2017 (FBI, 5/3). One of the admins posted that although being busy and race against the time, but he hopes this FBI group will always be exist and provide quality books. There are several reasons on why people do information sharing that is to develop personal relationship and managing image towards the others, to increase their skill, strength, and references, evaluative assessment, social fee and learning experience for the knowledge disseminator (Wang \& Noe, 2010).

\subsection{Education in the Telegram Group of FBI}

FBI Telegram group aims to share information regarding books, however there are members who want to get books or e-books information immediately without attempt to look for it first. One of the admins admits that many of the members know the book sources they need but somehow they cannot find the book themselves. Meanwhile, she is always able to find the book needed with the same book source. However, the informant wants the members to at least try to look for the book themselves before asking for other's help. The education process is given by asking the members to read the rules regarding books finding include using search menu on Telegram in order to check whether the books needed have been posted before or not. In the context of Telegram using, not all of the members know how to use features provided on Telegram. The members often tell the others on how to use the features on Telegram, for instance, when a member requests for book has been shared, the other members then will respond by asking him/her to use the search feature, also they will provide the know-how, such as "Guys, to help you find the book needed, please look at the shared media. Click it, there will be a picture shows, then click the picture you would 
like to view or download" or "Guys, to help you find the book you want please read the knowhow on the Pinned Message button, open Profile, click Share Media, click the image, view the file name, then go back to wall menu, click Search". The content of Pinned Message of FBI Telegram group from June 1st till July 30th July 2017 is the guidance to share and browse information in the group. A group member created a tutorial gif format on how to search media file in the group. Since the desktop version of Telegram was blocked by Indonesia government on July 14th 2017, some members discuss on the alternative access to the group.

\section{CONCLUSION}

Books information sharing on Telegram group of FBI has been running since February 2017 till today. The group rules have been made and placed on the Pinned Message in order to be visible for all the members. As for the content, the FBI Telegram group has been used as its mission that is as the media for Indonesian Book Lovers to discuss, share, and exchange books or information regarding books including e-books. However, many of the members, particularly the newbies in the group, have not been optimal in using the Telegram features yet especially the Search feature, resulting in repeated question asked in the group. Books information sharing in FBI Telegram group including mostly forwarded information from other group or channel, there is also resume and meta data, direct link to e-book and also e-book file. This books sharing activity is considered very helpful for many people as there are many thank you note from the members to the others or to the admins in the group. The activities of FBI Telegram group members can be viewed from the interaction among members in the group, information collection process, identification, analysis, validation and investigation and information sharing also education given in the group. This part presents the conclusion which may contain the summary of research findings and discussion. Recommendations could also be proposed in this part. [Times New Roman 11, normal].

\section{REFERENCES}

Brewer, J. D. (2000). Ethnography. Buckingham · Philadelphia: Open University Press.

Calo, K. M., Cenci, K., Fillottrani, P., \& Estevez, E. (2012). Information Sharing- Benefits. JCS\&T Vol. 12 No. 2 , 49-55.

Crichton, S., \& Kinash, S. (2003). Virtual Ethnography: Interactive Interviewing Online as Method. Canadian Journal of Learning and Technology Volume 29(2) Spring / printemps 2003.

Dalkir, K. (2005). Knowledge Management in Theory and Practice. Burlington, MA: Elsevier Inc.

Davenport, T. H. (1997). Information Ecology. Oxford: Oxford University Press.

Du, J. T. (2013). Information Use and Information Sharing in Marketing: A Diary Study. Proceedings of the American Society for Information Science and Technology Vol. 49 Issue 1, http://onlinelibrary.wiley.com/doi/10.1002/meet.14504901290/pdf.

Food and Agriculture Organization of The United Nations. (2009). Information and Knowledge Sharing. Rome: FAO.

Genzuk, M. (2003). A Shynthesis of Ethnographic Research. Occasional Paper Series. Los Angeles: Center for Multilingual, Multicultural Research (Eds.) Rossier School of Education, University of Southern California .

Hatala, J.-P., \& Lutta, J. G. (2009). Managing Information Sharing Within an Organizational Setting: A Social Network Perspective. Performance Improvement Quarterly, 21(4), 5-33.

Hine, C. (2000). Virtual Ethnography. London, Thosands Oaks, New Delhi: SAGE Publications. Huysman, M., \& Wit, D. d. (2002). Knowledge Sharing in Practice. Netherlands: Springer Netherlands. 

Institut Agama Islam Negeri Surakarta: Surakarta, 5-6 August 2017

Jackson, B. A. (2000). The Use of Collaborative Electronic Media for Information Sharing: an Exploratory Study of Determinants. Journal of Strategic Information Systems 9, 129-154.

Janus, S. S. (2016). Becoming a Knowledge-Sharing Organization: A Handbook for Scaling Up Solutions through Knowledge Capturing and Sharing. Washington: The World Bank.

Steinmetz, K. F. (2012). Message Received: Virtual Ethnography in Online Message Boards . International Journal of Qualitative Methods Vol 11, No 1, 26-39.

Telegram Messenger LLP. (2017). Telegram Google Play. support@telegram.org: Telegram Messenger LLP.

Tsui, L., Chapman, S. A., Schnirer, L., \& Stewart, S. (2006). A Handbook on Knowledge Sharing: Strategies and Recommendations for Researchers, Policymakers, and Service Providers. Alberta: Community-University Partnership .

Wang, S., \& Noe, R. A. (2010). Knowledge sharing: A review and directions for future research. Human Resource Management Review 20, 115-131. 